\title{
Louse (Insecta: Phthiraptera) infestations of European Bee-eaters (Merops apiaster Linnaeus, 1758) at Albertirsa, Hungary
}

\author{
Kata Karáth ${ }^{1}$, Tibor István Fuisz ${ }^{2}$, Zoltán Vas ${ }^{2 *}$
}

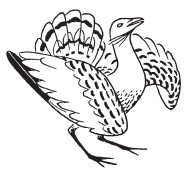

Kata Karáth, Tibor István Fuisz \& Zoltán Vas 2013. Louse (Insecta: Phthiraptera) infestations of European Bee-eaters (Merops apiaster Linnaeus, 1758) at Albertirsa, Hungary. - Ornis Hungarica 21(2): 33-37.

Abstract Colonial breeding birds such as the European Bee-eater (Merops apiaster), are perfectly suited for ectoparasitological studies, as their elaborate social life and frequent body-to-body contacts induce high prevalence of louse (Phthiraptera) infestations. In this study we investigated a large breeding colony at Albertirsa, Hungary, and measured the louse burden of the breeding population. With more than 200 pairs nesting in the loess wall there, it may be Hungary's largest colony of European Bee-eaters. We sampled breeding birds and compared their louse burdens between age groups and sexes. We report the prevalence, mean and median intensity of infestations of the three louse species harboured by the Bee-eaters, and the results of louse burden comparisons between age groups and sexes.

Keywords: ectoparasite, lice, parasitism, preening

Összefoglalás A koloniális fészkelésủ madarak, mint a gyurgyalag (Merops apiaster) különösen alkalmasak ektoparazitológiai kutatásokra, köszönhetően az összetett szociális viselkedésükből adódó gyakori testi érintkezések miatt fellépő magas fertőzöttségi aránynak. Vizsgálatunk során felmértük az Albertirsán (Pest megye, Magyarország) található kolónia tolltetű (Phthiraptera) fertőzöttségét. Ez a kolónia több mint 200 fészkelő párral valószínűleg Magyarország legnagyobb gyurgyalagtelepe. Jelen dolgozatban közöljük a különböző gyurgyalag korés ivarcsoportok fertőzöttségi mérőszámait mindhárom, a gyurgyalagot fertőző tetüfaj esetében, illetve a kor- és ivarcsoportok fertőzöttségének összehasonlítása során kapott eredményeket.

Kulcsszavak: ektoparazita, tetü, élősködés, tollászkodás

${ }^{1}$ Institute for Biology, Faculty of Veterinary Science, Szent István University, Budapest, István utca 2., 1078 Hungary, e-mail: katakarath@gmail.com

${ }^{2}$ Department of Zoology, Hungarian Natural History Museum, Budapest, Baross utca 13., 1088 Hungary

*Corresponding author: e-mail: vas@nhmus.com

\section{Introduction}

The European Bee-eater (Merops apiaster) is a suitable candidate for ectoparasitological research as their elaborate social life and frequent body-to-body contacts of the host specimens induce high prevalence of louse (Phthiraptera) infestations (Hoi et al. 1998). Representatives of both of the suborders of lice (Insecta: Phthiraptera) (2 species of 2 genera from the Ischnocera suborder, and 1 species of 1 genera from the Amblycera suborder) are harboured by the European Bee-eater (Price et al. 2003). Hence, the differences between the infestation levels and dispersion strategies of the members of the two markedly different louse taxa can also be examined. 
Lice are wingless obligate ectoparasites living on the body surface of their hosts, feeding on the feathers and dead skin parts. They typically require direct physical contact between the host individuals for transmission (Price et al. 2003, Rózsa 2003). Lice affect both life expectancy and reproductive success of the hosts. The feather damage and reduced insulation caused by lice may cause higher mortality rates in infested hosts as it was shown in several bird species (Booth et al. 1993, Kose \& Møller 1999, Barbosa et al. 2003, Pap et al. 2005). Additionally, the theory of parasite-mediated sexual selection argues that females directly (evading infestation) and indirectly (securing parasite-resistant alleles for their offsprings) benefit from avoiding infested mates (Hamilton \& Zuk 1982, Clayton 1991, Able 1996, Pap et al. 2005).

The aim of our study was to survey the feather louse burden of European Bee-eaters in a large colony at Albertirsa, Hungary. We investigated the prevalence, mean and median intensity of infestation of each host-specific louse species of the European Bee-eaters, and compared them between the age groups and sexes of the hosts.

\section{Materials and methods}

The study site is located at Albertirsa at a loess wall and the field work was carried out in the breeding season (July-August) in 2012. The history of this colony - which is most probably the largest one in Hungary with more than 200 breeding pairs - is reported by Urbán et al. (2013).

European Bee-eaters were captured with mist nets at the breeding site. Sexes and two age groups $\left(2 \mathrm{y}: 2^{\text {nd }}\right.$ calendar year or $2+$ : at least $3^{\text {rd }}$ calendar year) of the hosts were identified (Baker 1993). During the ringing procedure the standard condition scores and the following biometric measurements were recorded: $3^{\text {rd }}$ primary's length, wing length, tale length (according to Svensson 1995). We used the standard method of ectoparasitological sampling (Johnson \& Clayton 2003, Rózsa 2003). We handled the birds' plumage with pyrethrin powder which is harmless to warm-blooded vertebrates (used and marketed drug in veterinary practise for pet birds), and then with a forceps we moved through gently the birds' plumage above a white tray for a standard 5 minutes time. Louse sampling preceded the measurements as recommended by Vas and Fuisz (2010) to avoid louse loss due to the handling of the host during the ringing procedure. Louse specimens were collected per hosts into an Eppendorf tube containing $70 \%$ ethanol. The identification of lice was carried out by the last author in the Hungarian Natural History Museum using a stereoscopic microscope.

Statistical analyses were carried out with Quantitative Parasitology 3.0 (Reiczigel \& Rózsa 2005). Prevalences were compared with Fisher's exact test, mean intensities with bootstrap-t test, and median intensities with Mood's median test (Rózsa et al. 2000, Rózsa 2003, 2005). All reported $P$-values are two-tailed. The aggregation of louse distribution among host individuals was estimated by the ratio of variance of abundance and mean abundance. Values below 8 indicate aggregated distribution (Rózsa 2003).

\section{Results and discussion}

Presence of all the three host-specific louse species of the European Bee-eaters was detected in our samples: Brueelia apiastri 


\begin{tabular}{|l|c|c|c|c|}
\hline & Males $(N=38)$ & Females $(N=28)$ & $\mathbf{2 y}(N=32)$ & $\mathbf{2 +}(N=34)$ \\
\hline Brueelia prevalence & 0.71 & 0.86 & 0.78 & 0.76 \\
\hline Meropoecus prevalence & 0.95 & 0.89 & 0.90 & 0.94 \\
\hline Meromenopon prevalence & 0.026 & 0.14 & 0.031 & 0.12 \\
\hline Brueelia mean intensity & 2.96 & 3.92 & 3.88 & 2.96 \\
\hline Meropoecus mean intensity & 7.75 & 4.20 & 7.34 & 5.34 \\
\hline Meromenopon mean intensity & 1.00 & 1.00 & 1.00 & 1.00 \\
\hline Brueelia median intensity & 2.00 & 3.00 & 4.00 & 2.00 \\
\hline Meropoecus median intensity & 6.50 & 4.00 & 6.00 & 4.00 \\
\hline Meromenopon median intensity & 1.00 & 1.00 & 1.00 & 1.00 \\
\hline Brueelia aggregation ratio & 2.33 & 3.120 & 2.22 & 3.62 \\
\hline Meropoecus aggregation ratio & 4.14 & 2.07 & 4.26 & 3.73 \\
\hline Meromenopon aggregation ratio & 1.00 & 0.89 & 1.00 & 0.91 \\
\hline
\end{tabular}

Table 1. Descriptive statistics of louse infestation measures in the hosts' age groups and sexes (host age: $2 \mathrm{y}: 2^{\text {nd }}$ calendar year, $2+: 3^{\text {rd }}$ calendar year or more)

1. táblázat Fertőzöttségi mérőszámok a gazdamadarak kor- és ivarcsoportjaiban (gazdamadarak kora: 2y: 2. naptári év, 2+: legalább 3. naptári év)

(Denny, 1842), Meropoecus meropis (Denny, 1842) (both Ischnoceran species), and Meromenopon meropis (Clay \& Meinertzhagen 1941) (Amblycera). Hereafter we refer to these species by mentioning only their generic name. Firstly we calculated the descriptive statistics of louse infestation measures of each species for the whole host sample $(N=66)$. Prevalence was 0.76 in the case of Brueelia, 0.91 in the case of Meropoecus, and 0.07 in the case of Meromenopon; mean intensity was $3.42,6.21$, and 1.00 , respectively; and median intensity was 3.0, 5.0, and 1.0, respectively. Their aggregation ratios were $2.84,4.21$ and 0.94 , respectively. The measures of louse infestation in the age groups and sexes of the hosts are reported in Table 1. In general, the prevalences, mean and median intensities of Brueelia and Meropoecus were relatively high as it was expected by former results of Hoi et al. (1998) and Darolova et al. (2001). Meromenopon was found to be a much rarer ectoparasite of the European Bee-eater. The distributions of each louse species among host individuals were aggregated (Table 1), as expected from contagious parasites (Crofton 1971).

We compared the Brueelia and Meropoecus louse burden between hosts' age groups and sexes. The sample size of the rare Meromenopon did not allow meaningful comparisons. We found no significant difference between the prevalences in either case $(P>$ $0.05)$; however, the mean and median intensity of Meropoecus infestation were significantly higher on males than on females $(P$ $=0.001$, and $P=0.035$, respectively, Table 1). A marginally significant difference $(P=$ 0.045 ) was also found in the case of Brueelia median intensity between younger and older birds, as $2 \mathrm{y}$ birds were characterised by a higher median intensity of infestation than $2+$ birds (Table 1). However, given the marginally significant $P$-value of this latter result, this phenomenon has to be confirmed on a larger dataset before discussing its potential causes. 
Our results showed that male European Bee-eaters tend to have higher intensity of Meropoecus infestation than females. We discuss some alternative, mutually non-exclusive alternative hypotheses explaining this phenomenon. Meropoecus lice live on the head and neck of the hosts, hence can not be removed by self-preening. European Bee-eaters have a biased sex ratio as about $60 \%$ of the adults are males $(58 \%$ in our sample), consequently, some males can not mate and may act as helpers at other breeding pairs (Cramp 1985). Pairs are known to preen each others' head and neck to control the louse infestation (Rózsa 2005), and the lack of this possibility in the unpaired males may be responsible for the higher intensity of infestation. The more frequent bodily contacts of males (e.g. fights) may also af-

\section{References}

Able, J. D. 1996. The contagion indicator hypothesis for parasite-mediated sexual selection. - Proceedings of the National Academy of Science, USA 93: 2229-2233. doi: 10.1073/pnas.93.5.2229

Baker, K. 1993. Identification guide to the European non-passerines. - BTO, Thetford

Barbosa, A., Merino, S., Cuervo, J. J., de Lope, F. \& Møller, A. P. 2003. Feather damage of long tails in Barn Swallow Hirundo rustica. - Ardea 91: 85-90.

Booth, D. T., Clayton, D. H. \& Block, B. A. 1993. Experimental demonstration of the energetic cost of parasitism in free ranging hosts. - Proceeding of the Royal Society of London Series B 253: 125 129. doi: 10.1098/rspb.1993.0091

Clayton, D. H. 1991. The influence of parasites on host sexual selection. - Parasitology Today 12: 329334. doi: 10.1016/0169-4758(91)90211-6

Cramp, S. 1985. Birds of the Western Palaearctic. Vol. 4. - Oxford University Press, Oxford

Crofton, H. D. 1971. A quantitative approach to parasitism. - Parasitology 62: 179-193. doi: 10.1017/ S0031182000071420

Darolova, A., Hoi, H., Kristofik, J. \& Hoi, C. 2001. Horizontal and vertical ectoparasite transmission of three species of Malophaga, and individual variation in European Bee-eaters. - Journal of Parasitology 87: 256-262. fect the results. On the other hand, it is also possible that females experience a louse loss during the breeding season by louse transmission to the chicks. This latter hypothesis requires further research about louse transmission strategies.

\section{Acknowledgement}

We are grateful to Sándor Urbán and his colleagues for the opportunity to carry out the field work at the Albertirsa Bee-eater colony. We also thank the two reviewers for their valuable comments and corrections.

Supported by the National Scientific Research Fund of Hungary (OTKA grant no. 108571

Hamilton, W. D. \& Zuk, M. 1982. Heritable true fitness and bright birds: a role of parasites? - Science 218 : 384-387. doi: 10.1126/science. 7123238

Hoi, H., Darolova, A., Koenig, C. \& Kristofik, J. 1998. The relation between colony size, breeding density and ectoparasite loads of adult European Bee-eaters (Merops apiaster). - Ecoscience 5: 156-163.

Johnson, K. P. \& Clayton, D. H. 2003. The biology, ecology, and evolution of chewing lice. 449-476. - In: Price, R. D., Hellenthal, R. A., Palma, R. L., Johnson, K. P. \& Clayton, D. H. (eds.) The chewing lice: world checklist and biological overview. - Illinois Natural History Survey, Champaign pp. 449-476.

Kose, M. \& Møller, A. P. 1999. Sexual selection, feather breakage and parasites: the importance of white spots in the tail of the Barn Swallow (Hirundo rustica). - Behavioral Ecology and Sociobiology 45: 430-436. doi:10.1046/j.1420-9101.2003.00660.x

Pap, P. L., Tökölyi, J. \& Szép, T. 2005. Frequency and consequences of feather holes in Barn Swallows (Hirundo rustica). - Ibis 147: 169-175. doi: 10.1111/j.1474-919x.2004.00386.x

Price, R. D., Hellenthal, R. A., Palma, R. L., Johnson, K. P. \& Clayton, D. H. (eds.) 2003. The chewing lice, world checklist and biological overview. - Illinois natural History Survey, Champaign 
Reiczigel, J. \& Rózsa, L. 2005. Quantitative Parasitology 3.0. - Budapest

Rózsa, L. 2003. A madarak tetvei (Phthiraptera) [Avian lice (Phthiraptera)]. - Állattani Közlemények 88: 2-29. (in Hungarian with English Summary)

Rózsa, L. 2005. Élősködés: az állati és emberi fejlődés motorja [Parasitism: a driving force of animal and human evolution]. - Medicina Könyvkiadó Rt., Budapest (in Hungarian)

Rózsa, L., Reiczigel, J. \& Majoros, G. 2000. Quantifying parasites in samples of hosts. - Journal of Parasitology 86: 228-232. doi: 10.1645/ 0022-3395(2000)086[0228:QPISOH]2.0.CO;2
Svensson, L. 1995. Útmutató az európai énekesmadarak határozásához [Identification guide to the European passerines]. - Magyar Madártani és Természetvédelmi Egyesület, Budapest

Urbán, S., Túri, K., Vas, Z.\& Fuisz, T. I. 2013. A successful habitat reconstruction effort, the short history of the European Bee-eater (Merops apiaster) colony at Albertirsa. - Ornis Hungarica 21(2): 47-51.

Vas, Z. \& Fuisz, T. I. 2010. Ringing procedure can reduce the burden of feather lice in Barn Swallows (Hirundo rustica). - Acta Ornithologica 45: 203207. doi: 10.3161/000164510X551345

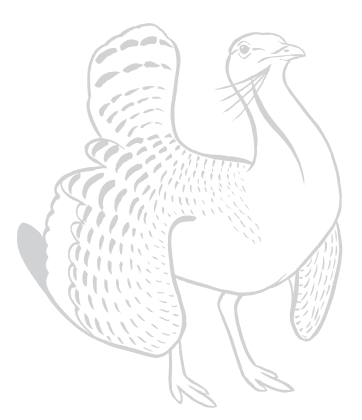

